\title{
ISOLATION OF MICROSPORUM GYPSEUM FROM THE HAIRCOAT OF HEALTH WILD FELIDS KEPT IN CAPTIVITY IN BRAZIL
}

\author{
Henri Donnarumma Levy Bentubo ${ }^{1 *}$; José Daniel Luzes Fedullo²; Sandra Helena Ramiro Corrêa²; Rodrigo Hidalgo \\ Friciello Teixeira²; Selene Dall'Acqua Coutinho ${ }^{1}$
}

\author{
${ }^{1}$ Faculdade de Medicina Veterinária, Universidade Paulista, São Paulo, SP, Brasil; ${ }^{2}$ Fundação Parque Zoológico de São Paulo, \\ São Paulo, SP, Brasil
}

Submitted: August 25, 2005; Returned to authors for corrections: January 23, 2006; Approved: March 15, 2006

\begin{abstract}
Dermatophytes are fungi that cause superficial mycoses in animals and humans. While studies have shown that domestic cats (Felis catus) are often asymptomatic carriers of dermatophytes, and thus a significant source of infection, this aspect has not been studied in relation to their wild relatives. The present study was aimed at determining the presence of dermatophytes on the haircoat of healthy wild felids, kept in captivity at "Fundação Parque Zoológico de São Paulo". Samples were taken from 130 adult animals of both sexes: 25 lions (Panthera leo), 12 tigers (Panthera tigris), 6 jaguars (Panthera onca), 4 leopards (Panthera pardus), 2 snow leopards (Panthera uncia), 2 pumas (Puma concolor), 2 cheetahs (Acinonyx jubatus), 1 ocelot (Leopardus pardalis), 28 tiger cats (Leopardus tigrinus), 10 margays (Leopardus wiedii), 8 geoffroy's cats (Leopardus geoffroyi), 22 jaguarundis (Herpailurus yagouaroundi) and 8 pampas cats (Oncifelis colocolo). The samples were obtained by rubbing the haircoat of the animals with squares of sterile carpet, and then seeded onto Petri dishes containing Mycobiotic agar (Difco ${ }^{\mathrm{TM}}$ ). The plates were incubated at $25^{\circ} \mathrm{C}$ for 4 weeks. The isolates were subcultured in Sabouraud dextrose agar supplemented with chloramphenicol $(100 \mathrm{mg} / \mathrm{L})$ and cultured on slides for posterior identification by their macro- and microscopic characteristics. Microsporum gypseum was isolated from two apparently healthy lionesses (1.6\%), both kept in terrariums. The most prevalent contaminants were of the genera Penicillium (27.9\%); Cladosporium (24.5\%); Acremonium (12.1\%); Scopulariopsis and Chrysosporium (9.8\%); and Aspergillus (5.3\%). The occurrence of dermatophytes in the haircoat of healthy wild felids, maintained in captivity, confirms their status as asymptomatic carriers and characterizes them as sources of infection for other animals and for humans.
\end{abstract}

Key words: dermatophytes, Microsporum gypseum, dermatophytosis, wild felids

\section{INTRODUCTION}

Dermatophytes are mycelial and keratinophylic fungi of the mold group, originally saprobial, but have adapted themselves to animal and human parasitism through evolution (20). Infection occurs through direct contact with the spores or hyphae of any of the three genera, Microsporum, Trichophyton or Epidermophyton (20). The disease depends on predisposing factors, like a failure in mucosa integrity or the skin surface, exposure to ultraviolet radiation, physical-chemical factors, temperature, the presence of another disease or the effect of immunosuppressor medication $(1,26)$.

Dermatophytes are the most important microorganisms which cause superficial mycosis and the lesions are characterized by circular disposition, desquamation, alopecia and erythema of the edges (20). The prevalence of dermatophytes varies according to geographical location, season or living conditions and the manipulation to which the susceptible animal or human

*Corresponding Author. Mailing address: Rua Estevam Ribeiro Rezende, 228. 05202-140, São Paulo, SP, Brasil. Te1.: (+5511) 3917-2327. E-mail: hbentubo@yahoo.com.br 
is exposed (3); however, in general, they occur more commonly in countries with a hot and humid climate (4).

In domestic animals $M$. canis, $M$. gypseum and $T$. mentagrophytes are the main species involved in infections (4). Among these, M. canis assumes a notable relevance as the most isolated dermatophyte in cats $(27,38)$.

M. canis can be isolated in up to $88 \%$ of apparently healthy cats (38); this asymptomatic carrier state of the domestic cat is of utmost importance because animal host reservoirs represent an infection risk for the human population and a public health concern $(5,38)$. Cats which live in groups, which have contact with non-domesticated cats or that are carries of viral immunosuppressor infections represent risks for dermatophytosis dissemination $(27,35,38)$.

The fungal microbiota of domestic cat haircoat is principally composed of fungi acquired from the environment (25). The most commonly isolated genera are Aspergillus, Penicillium, Cladosporium and Alternaria; although, Fusarium, Geotrichum, Cephalosporium, Curvularia, Paecilomyces, Rhizopus, Chrysosporium, Nigrospora, Scopulariopsis, Phoma, Absidia, Helminthosporium, Glicocadium and Mucor are also cited by literature $(6,25,33,35)$.

Different species of wild animals and laboratory species may also constitute host reservoirs of the Microsporum spp. and Trichophyton spp. $(6,8,19,24)$.

In 1999, a case of dermatophytosis was described in three wild felids in Florida, USA. Three specimens of cougar (Puma concolor), one of them infected by $M$. gypseum and the other two by T. mentagrophytes (33). A small epidemic focus of ringworm cased by $M$. canis was reported in lions (Panther leo) (2). Dermatophytes were also isolated from the haircoat of a tiger (Panthera tigris) (13). Research in dermatophytes in Brazil in one specimen of each of the following wild felids: ocelot (Felis pardalis), lion (Panthera leo) and tiger (Panthera tigris), isolated M. gypseum in the ocelot (6).

Given the considerable zoonotic and zoopathogenic potential of dermatophytes, it is important to research and identify these fungi in the resident and/or transitory microbiota of the haircoat of healthy wild felids, to determine possible infection sources in asymptomatic carriers. With this objective in mind this research sought to detect the presence of dermatophyte fungi on the haircoat of healthy wild felids maintained in captivity.

\section{MATERIALS AND METHODS}

\section{Animals}

Samples were taken from 130 adult animals of both sexes: 25 lions (Panthera leo), 12 tigers (Panthera tigris), 6 jaguars (Panthera onca), 4 leopards (Panthera pardus), 2 snow leopards (Panthera uncia), 2 pumas (Puma concolor), 2 cheetahs (Acinonyx jubatus), 1 ocelot (Leopardus pardalis), 28 tiger cats
(Leopardus tigrinus), 10 margays (Leopardus wiedii), 8 geoffroy's cats (Leopardus geoffroyi), 22 jaguarundis (Herpailurus yagouaroundi) and 8 pampas cats (Oncifelis colocolo). The anesthetic protocol was the same as that used for routine handling of felids in this zoo. The animals were sedated using anesthetic darts containing $1.0 \mathrm{mg} / \mathrm{kg}$ weight xylazine and $10.0 \mathrm{mg} / \mathrm{kg}$ weight ketamine. If more prolonged relaxation was required, $0.5 \mathrm{mg} / \mathrm{kg}$ diazepam was applied.

\section{Samples}

Samples were collected according to the carpet technique (23), rubbing previously sterilized carpet squares on the animals' dorsum. These carpet pieces were sent to laboratory in up to 24 hours, and then seeded by impression on plates containing Mycobiotic (Difco ${ }^{\mathrm{TM}}$ ) agar medium. The material was incubated at a temperature of $25^{\circ} \mathrm{C}$ and readings were taken every three days, for a period of four weeks, submitting each mold to subculture in Sabouraud dextrose agar with chloranphenicol (100 mg/L), for sample maintenance.

\section{Molds isolated and its identification}

All colonies were submitted for slide culture (30), in potato medium agar (Microbiology ${ }^{\mathrm{TM}}$ ). The material was incubated at $25^{\circ} \mathrm{C}$ until presenting sufficient growth for slide and coverslip mounting, with methylene blue staining. The fungi were identified by their macro- and microscopic morphological characteristics $(21,28)$.

\section{RESULTS}

Two hundred and sixty seven (267) mycelial fungi strains were isolated in the 130 animals under study, Microsporum gypseum was isolated in $1.6 \%$ of these. M. gypseum was obtained for two lionesses (Panthera leo) which showed no signs of infection, although one of these animals was seropositive for Feline Immunodeficiency Virus (FIV).

In this work, the isolation of 265 mold contaminants was obtained: 74 strains of Penicillium spp. (27.9\%); 65 of Cladosporium spp. (24.5\%); 32 of Acremonium spp. (12.1\%); 26 of Scopulariopsis spp. and Chrysosporium spp. (9.8\%); 14 of Aspergillus spp. (5.3\%); 6 of Fusarium spp. (2.2\%); 4 of Exophiala spp. (1.5\%); 3 of Micelia sterilia (1.1\%); 2 of Chaetomium spp. and Geotrichum spp. (0.7\%); and a strain of each one genus: Pseudallescheria sp, Phialophora sp, Helminthosporium sp, Verticillium sp, Drechslera sp, Paecilomyces sp, Trichoderma sp, Alternaria sp, Phoma sp, Rhinocladiella sp and Mucor sp (0.4\%).

\section{DISCUSSION}

M. gypseum, a mycelial keratinophylic fungus isolated in this study, is a geophilic dermatophyte. Humidity, $\mathrm{pH}$ and fecal 
contamination constitute relevant factors in the determination of its presence and of other keratinophylic fungi in the soil (36). Both lionesses, from which the isolation of M. gypseum was achieved, were maintained in confinement with earth floors, therefore, this fact must have influenced the acquisition and permanence of these fungi in the microbiota of the haircoat of these animals.

Isolation of this fungus in domestic animals is variable, according to the research literature available. While some authors obtained a frequency of $0.6 \%$ in 173 healthy cats studied (30), other authors verified positivity of $8 \%$ for this fungus in 100 cats in the same conditions (11). A frequency of $7.7 \%$ was obtained in the isolation of M. gypseum in dogs, cats, rabbits, chickens, ruminants and horses studied in Iran (18) and 9\% in healthy cats and dogs studied in Belo Horizonte City, Brazil (24). However, these results could be even higher, like in India, where M. gypseum was found to be one of the principal dermatophytes isolated in dogs and bovine, representing around $40 \%$ of those isolated in these animals (29).

Like the other dermatophytic species, M. gypseum possesses the capacity to infect animal and human tissue using keratin as its principal substrate. This fungus has been referred to in the literature as the cause of infections in different domestic and wild animal species. Some authors consider it to be the most frequent dermatophytosis causal agent in rabbits (18). It is referred to as responsible for a number of dermatophytosis cases in cats (16), in interspecies outbreaks involving cats and humans (5), and even described in clinical findings of infection associated with Dermatophilus congolensis in Arabian camels (Camelus dromedarius) (14) and Malassezia pachydermatis in dogs (34). In Brazil, there are two cases of dermatophytosis by M. gypseum involving a gray wolf cub (Canis lupus) and a camel (Camelus bactrianus) (9). A retrospective study realized in the USA, found 14 cases of dermatophytosis in red pandas (Ailurus fulgens), which occurred between 1980 and 1996, where seven animals presented scabby, alopecia lesions, while another six animals presented more serious clinical evidence of ulceration, necrotic skin and purulent exudate; the disease severity of one of the animals was not documented, although, $M$. gypseum was the only fungus isolated in all cases (17).

With respect to the lack of research work of this nature in wild felids, $M$. gypseum has been cited as the cause of infections in these animals. In 1995 the first reported case of dermatophytosis in a wild felid in Brazil was described in a specimen of ocelot (Leopardus pardalis) (6). M. gypseum was also identified as the causal agent of dermatomycosis in a male specimen of puma (Puma concolor), among 30 animals of a free ranging group submitted to monitoring in Florida, USA (33).

Although M. gypseum is not the most frequently found species in human mycotic processes, it is the most common geophylic fungus (22). Recent reports in Brazil (22), Italy (32),
Slovakia (37) and Japan (15) reaffirm the existence of these fungi in human skin lesions.

Generally the dermatophytes cause dermatomycosis, $M$. gypseum has been described as causing subcutaneous mycosis in humans (7) and has been associated with opportunistic infections occurring in patients with Human Immunodeficiency Virus (HIV) (10). In this project, one of the animals which was positive for M. gypseum presented seropositivity for Feline Immunodeficiency Virus (FIV), which reinforces the relation of immunosuppressor factors, cited in the literature, with the infection (35) and suggests the importance of these animals as asymptomatic carriers and possible infection sources for animals and/or technicians and workers, who may have direct contact with these carriers.

The saprobial contaminants isolated in greatest frequency in this survey were indicated by other authors $(3,4,11,25)$ from domestic dog and cat haircoat (Penicillium spp., Cladosporium spp., Scopulariopsis spp., Chrysosporium spp., and Aspergillus spp.).

Studies realized in different periods researching the anemophile microbiota of São Paulo City, confirmed the genera Cladosporium, Penicilium, Aspergillus and Acremonium as the most frequent molds and also refer to the isolation of Alternaria spp., Fusarium spp., Phoma spp., Trichoderma spp. (12). It is well known that the body surface microbiota of animals, both resident and transitory, is changed by the environmental microorganisms (12).

The existence of dermatophytes on the haircoat of healthy wild felids, not only elevates the risk that these animals eventually become ill, but also inserts them in the category of asymptomatic carriers, like their relatives the domestic cat, characterizing them as sources of fungal infection both for other animals and for human beings. Understanding this condition is essential in the adoption of prophylatic measures for sanitary maintenance for these animals and the professionals who maintain contact with them.

\section{RESUMO}

\section{Isolamento de Microsporum gypseum do pelame de felídeos selvagens sadios mantidos em cativeiro no Brasil}

Os dermatófitos são os fungos mais comumente associados às micoses superficiais em animais e homem. $\mathrm{O}$ estado de portador assintomático do gato doméstico o caracteriza como importante fonte de infecção, entretanto, até então, tal aspecto não foi pesquisado em relação a seus parentes selvagens. $\mathrm{O}$ objetivo desta pesquisa foi determinar a presença de dermatófitos no pelame de felídeos selvagens sadios, mantidos em cativeiro na Fundação Parque Zoológico de São Paulo. A amostragem foi constituída de 130 animais adultos de ambos os 
sexos, sendo 25 leões (Panthera leo), 12 tigres (Panthera tigris), 6 onças-pintadas (Panthera onca), 4 leopardos (Panthera pardus), 2 leopardos-das-neves (Panthera uncia), 2 suçuaranas (Puma concolor), 2 guepardos (Acinonyx jubatus), 1 jaguatirica (Leopardus pardalis), 28 gatos-do-mato-pequenos (Leopardus tigrinus), 10 gatos-maracajás (Leopardus wiedii), 8 gatos-domato-grandes (Leopardus geoffroyi), 22 gatos-mouriscos (Herpaylurus yaguaroundii) e 8 gatos-palheiros (Oncifelis colocolo). As amostras foram obtidas a partir da fricção de quadrados de carpete estéreis no pelame dos animais. Os carpetes foram então semeados em placas de Petri contendo ágar Mycobiotic (Difco $\left.{ }^{\circledR}\right)$ e incubadas a $25^{\circ} \mathrm{C}$ por 4 semanas. As colônias obtidas foram repicadas em tubos contendo ágar Sabouraud dextrose com cloranfenicol (100mg/L) e submetidas a microcultivo em lâmina, para posterior identificação através de suas características macro e microscópicas. Microsporum gypseum foi isolado de duas leoas $(1,6 \%)$ aparentemente saudáveis, ambas mantidas em terrários. Os contaminantes mais prevalentes foram dos gêneros Penicillium (27,9\%); Cladosporium (24,5\%); Acremonium (12,1\%); Scopulariopsis e Chrysosporium (9,8\%); e Aspergillus (5,3\%). A ocorrência de dermatófitos no pelame de felídeos selvagens sadios, mantidos em cativeiro, confirma seu estado de portador assintomático e os caracteriza como fontes de infecção para outros animais e para os seres humanos.

Palavras-chave: dermatófitos, Microsporum gypseum, dermatofitoses, felídeos selvagens

\section{REFERENCES}

1. Aljabre, S.H.M.; Richardson, M.D.; Scott, E.M.; Shankland, G.S. Germination of Trichophyton mentagrophytes on human stratum corneum in vitro. J. Med. Vet. Mycol., 30, 145-152, 1992.

2. Avram, A.; Alteras, I.; Carjewski, M.; Iliescu, M. Microsporie chez un groupe des lions en captivité. Mycopathologia (Den Haag). 9 , 288-295, 1958.

3. Boyanowski, K.J.; Ihrke, P.J.; Moriello, K.A.; Kass, P.H. Isolation of fungal flora from hair coats of shelter cats in the Pacific Coastal USA. Vet. Dermatol., 11, 143-150, 2000.

4. Cavalcanti, M.P.; Faustino, M.A.G.; Gomes-Filho, J.B.; Alves, L.C. Frequência de dermatófitos e fungos saprófitas em caninos e felinos com sintomatologia sugestiva de dermatopatia micótica atendidos no Hospital Veterinário da UFRPE. Clín. Vet., 24-28, 2003.

5. Costa, E.O.; Diniz, L.S., Benites, N.R.; Coutinho, S.D.; Carvalho, V.M.; Dutra, L.F.; Serra, E.G. Surtos interespecíficos de dermatomicoses por Microsporum canis e Microsporum gypseum. Rev. Saúde Publ., 28, 337-340, 1994

6. Costa, E.O.; Diniz, L.S.M.; Carvalho, V.M.; Coutinho, S.D.; Benites, N.R. Dermatoses observadas no homem e em animais de laboratório, domésticos e silvestres em São Paulo. Levantamento retrospectivo. Arq. Bras. Med. Vet. Zoot., 47, 601-607, 1995.

7. Fernandez-Torres, B.; Mayayo, E.; Boronat, J., Guarro, J. Subcutaneous infection by Microsporum gypseum. Br. J. Dermatol., 146, 311-313, 2002.

8. Fischman, O.; Camargo, Z.P.; Grinblat, M. Trichophyton mentagrophytes infection in laboratory white mice. Mycopathologia, $59,1135,1976$
9. Fischman, O.; Siqueira, P.A.; Baptista, G. Microsporum gypseum infection in a gray wolf (Canis lupus) and a camel (Camelus bactrianus) in a zoological garden. Mycosen., 30, 295-297, 1987.

10. Galhardo, M.C.; Wanke, B.; Reis, R.S.; Oliveira, L.A.; Valle, A.C. Disseminated dermatophytosis by Microsporum gypseum in an AIDS patient: response to terbinafine and amorolfine. Mycoses, 47, 238241,2004

11. Gambale, W.; Larsson, C.E.; Moritami, M.M.; Corrêa, B.; Paula, C.R.; Framil, V.M.S. Dermatophytes and other fungi of the haircoat of cats without dermatophyosis in the city of São Paulo, Brasil. Fel. Pract., 21, 29-33, 1993.

12. Gambale, W.; Purchio, A.; Groce, J. Flora fúngica anemófila da grande São Paulo. Rev. Microbiol., 8, 74-79, 1997.

13. Gierloff, B.C.H.; Katic, I. Om anvendelse of griseofulvin specielt I veterinaer praksis. Nord. Vet. Med., 13, 571-592, 1961.

14. Gitao, C.G.; Agab, H.; Khalifalla, A.J. An outbreak of a mixed infection of Dermatophilus congolensis and Microsporum gypseum in camels (Camelus dromedarius) in Saudi Arabia. Rev. Sci. Tech., 17, 749$755,1998$.

15. Haga, R.; Suzuki, H. Tinea capitis due to Microsporum gypseum. Eur. J. Dermatol., 12, 367-368, 2002.

16. Kano, R.; Yasuda, K.; Nakamura, Y.; Hasegawa, A. Microsporum gypseum isolated from a feline case of dermatophytosis. Mycoses, 44, 338-341, 2001.

17. Kearns, K.S.; Pollock, C.G.; Ramsay, E.C. Dermatophytosis in red pandas (Ailurus fulgens fulgens): a review of 14 cases. J. Zoo. Wildl. Med., 30, 561-563, 1999.

18. Khosravi, A.R.; Mahmoudi, M. Dermatophytes isolated from domestic animals in Iran. Mycoses, 46, 222-225, 2003.

19. Knudtson, W.; Gates, C.; Ruth, G.; Hadley, L.D. Trichophyton mentagrophytes dermatophyosis in wild fox. J. Wildl. Dis., 16, 465 468, 1980

20. Lacaz, C.S.; Porto, E.; Martins, J.E.C. Micologia médica-fungos, actinomicetos e algas de interesse médico. Sarvier Ltda, São Paulo, 1991, 695p.

21. Larone, D.H. Medically important fungi - a guide to identification ASM Press, Washington, 1995, 274p.

22. Lopes, J.O.; Alves, S.H.; Benevenga, J.P. Dermatofitose humana por Microsporum gypseum no interior do Rio Grande do Sul: estudo clínico. An. Bras. Dermatol., 67, 71-72, 1992.

23. Mariat. F.; Adam-Campos, C. La technique du carré du tapis, méthode simple de prélevement dans les mycoses superficielles. Ann. Inst. Pasteur., 113, 666-668, 1967.

24. Moreira, Y.K.; Barbosa, M.; Moreira, E.C.; Fonseca, I.C. Fungos queratinofílicos patogênicos para o homem, nos pêlos e pele de cães e gatos normais. Arq. Esc. Vet. Belo Horizonte, 22, 141-144, 1970.

25. Moriello, K.A.; DeBoer, D.J. Fungal flora of the coat of pet cats Am. J. Vet. Res., 52, 602-606, 1991.

26. Ogawa, H.; Summerbell, R.C.; Clemons, K.V.; Koga, T.; Ran, Y-P.; Rashid, A.; Sohnle, P.G.; Stevens, D.A.; Tsuboi, R. Dermatophytes and host defence in cutaneus mycoses. Med. Mycol., 36, 166-173, 1998.

27. Pier, A.C.; Moriello, K.A. Parasitic relationship between Microsporum canis and the cat. Med. Mycol., 36, 271-275, 1998.

28. Quinn, P.J.; Carter, M.E.; Markey, B.; Carter, G.R. Clinical veterinary microbiology. Wolfe, London, 1994: 648p.

29. Ranganathan, S.; Balajee, A.S.; Raja, S.M. A survey of dermatophytosis in animals in Masdras, Índia. Mycopathologia, 140, 137-140, 1997.

30. Riddell, R.W. Permanent stained mycological preparations obained by slide culture. Mycologia, 42, 265-270, 1950.

31. Romano, C.; Valenti, L.; Barbara, R. Dermatophytes isolated from asymptomatic stray cats. Mycoses, 40, 471-472, 1997.

32. Romano, C.; Massai, L. Proximal subungueal hyperkeratosis of the big toe due to Microsporum gypseum. Acta Derm. Venereol., 81, 371-372, 2001. 
33. Rotstein, D.S.; Thomas, R.; Heimick, K.; Citino, S.B.; Taylor, S.K.; Dumbar, M.R. Dermatophyte infection in free-ranging Florida panthers (Felis concolor coryi). J. Zoo Wildl. Med., 30, 281-284, 1999.

34. Saridomichelakis, M.N.; Koutinas, A.F.; Bourdzi-Hatzopoulou, E.; Petridou, E.; Hatziefremidis, I.; Leontides, L. Recovery of Microsporum gypseum and Malassezia pachydermatis from the nasal bridge in various dog groups. Vet. Rec., 145, 171-172, 1999.

35. Sierra, P.; Guillot, J.; Jacob, H.; Bussiéras, S.; Chermette, R. Fungal flora on cutaneous and mucosal surfaces of cats infected with feline immunodeficiency virus or feline leukemia virus. Am. J. Vet. Res., $61,158-161,2000$.
36. Ulfig, K.; Plaza, G.; Sztyler, A.; Bronder, J.; Terakowski, M.; Guarro, $\mathrm{J}$. General assessment of the influence of a municipal landfill site and environmental factors on the occurrence of keratinolytic fungi in soil. Rocz. Panstw. Zakl. Hig., 51, 167-181, 2000.

37. Vollekova, A.; Tothova, I.; Kolibasova, K.; Sevcekova, A.; Baumgartner, J. Atypical infection caused by Microsporum gypseum mimicking circumscribed scleroderma. Bratisl. Lek. Listy., 97, 162164, 1996.

38. Zaror, L.; Fischman, O.; Vilanova, A.; Levites, J. The role of cats and dogs in the epidemiological cycle of Microsporum canis. Mykosen, 29, 185-188, 1986. 